https://doi.org/10.52058/2786-4952-2021-5(5)-143-152

Гавран Мар'яна Іванівна кандидат педагогічних наук, доцент, доцент кафедри іноземних мов, Національний університет «Львівська політехніка», вул. С. Бандери, 12, м. Львів, тел.: (067) 258-66-68, e-mailMariana.i.havran@lpnu.ua, https://orcid.org/0000-0003-1345-9235

Гавран Володимир Ярославович кандидат економічних наук, доцент, доцент кафедри менеджменту організацій, Національний університет «Львівська політехніка», вул. С. Бандери, 12, м. Львів, e-mail- Volodymyr.ya.havran@lpnu.ua, https://orcid.org/0000-0002-6833-941X

\title{
ПРОБЛЕМИ ТА ПЕРСПЕКТИВИ ОРГАНІЗАЦІЇ ДИСТАНЦІЙНОГО НАВЧАННЯ В ПРИВАТНИХ ЗВО ПОЛЬЩІ
}

Анотація. Стаття присвячена вивченню проблеми організації дистанційного навчання в приватних ЗВО Польщі. Вивчено та проаналізовано сучасний стан організації дистанційного навчання у приватних ЗВО Польщі, які з початку свого розвитку демонстрували зацікавленість у використанні різноманітних інформаційних технологій у навчальному процесі, адже заочне i дистанційне навчання стали там важливими формами надання освітніх послуг молоді та дорослим. Розглянуто трактування дистанційного навчання, онлайн навчання та електронного навчання та їхнє впровадження в освітній процес приватних 3ВО Польщі. Виокремлено та проаналізовано діяльність окремих польських приватних ЗВО з метою вивчення досвіду реалізації дистанційного навчання та форм онлайн навчання. Встановлено, що в сучасних умовах дистанційне навчання вже, здебільшого, розглядається як складний процес, що поєднує онлайн технології, платформи та ресурси 3 інструментами відеоконференцій 3 метою активного залучення студентів до навчального процесу, мінімізуючи відсутність живої комунікації, співпраці та взаємодії. Окреслено проблемні питання через реалізацію дистанційного навчання та певні проблеми в недержавних ЗВО Польщі, які часто пов'язані між собою і впливають на якість дистанційного навчання. Доведено, що успішність процесу організації віддаленого навчання залежить не лише від цифрової компетентності науково-педагогічних працівників 3ВО, їхнього ентузіазму і обізнаності в новітніх інформаційно-комунікаційних технологіях, але й виважених і своєчасних організаційних заходів зі сторони навчальних закладів, фінансової підтримки зі сторони держави у вигляді субсидій та додаткових виплат, належного нормативно-правового регулювання і загально сприйняття суспільством нових форм навчального процесу та надання онлайн освітніх послуг. 
Журнал «Герспективитаінноваціїнауки»

(Серія«Гедагогіка», Серія«ПЕихологія», Серія «Медицина»

№5(5) 2021

Ключові слова: дистанційне навчання, приватні ЗВО, навчальний процес, інформаційно-комунікаційні технології, Польща.

Havran Maryana Ivanivna Candidate of Pedagogical Sciences, associate professor, associate professor of Foreign Languages Department, Lviv Polytechnic National University, S. Bandera St., 12, Lviv, tel.: (067) 258-66-68, e-mailMariana.i.havran@lpnu.ua, http://orcid.org/0000-0003-1345-9235

Havran Volodymyr Yaroslavovych Candidate of Economical Sciences, associate professor, associate professor of Management of Organizations Department, Lviv Polytechnic National University, S. Bandera St., 12, Lviv, e-mailVolodymyr.ya.havran@1pnu.ua, https://orcid.org/0000-0002-6833-941X

\title{
PROBLEMS AND PROSPECTS OF ORGANIZING DISTANCE LEARNING IN PRIVATE HEIS OF POLAND
}

\begin{abstract}
The article is devoted to the study of the problem of organizing distance learning in private HEIs of Poland. The current state of the organization of distance learning in private HEIs has been studied and analyzed. Since the beginning of its development they have shown interest in using various information technologies in the educational process, as part-time study and distance learning are an integral part of their educational processes. The interpretation of distance learning, online learning and e-learning and their introduction into the educational process of private HEIs of Poland are considered. The activities of some Polish private HEIs have been singled out and analyzed in order to study the experience of implementing distance learning and forms of online learning. It is established that in modern conditions distance learning is mostly considered as a complex process that combines online technologies, platforms and resources with video conferencing tools to actively involve students in the learning process, minimizing their lack of live communication, cooperation and interaction. The authors emphasize on problematic issues due to the implementation of distance learning and certain problems in nonpublic HEIs of Poland, which are often interconnected and affect the quality of distance learning. It is proved that the success of the process of organizing distance learning depends not only on the digital competence of scientific and pedagogical staff, their enthusiasm and awareness of the latest information and communication technologies, but also balanced and timely organizational measures by educational institutions, financial support from the state subsidies and additional payments, proper legal regulation and general public perception of new forms of remote learning and online educational services.
\end{abstract}

Keywords: distance learning, private HEIs, educational process, information and communication technologies, Poland. 
Постановка проблеми. Карантинні обмеження i локдауни через поширення вірусу COVID-19, з яким стикнулося людство впродовж останніх двох років, зумовили пришвидшений розвиток інформаційно-комунікаційних технологій в освітньому процесі, змінили традиційні підходи до навчання, підкресливши важливість дистанційного навчання та довівши необхідність використання різноманітних онлайн ресурсів, додатків та платформ у навчальному процесі. Усі ЗВО України водночас зіткнулися 3 проблемою швидкої адаптації найсучасніших освітніх технологій, онлайн навчання та всіх можливих засобів та ресурсів цифрової освіти до зростаючої потреби надання якісних освітніх послуг у віддаленому режимі.

3 метою покращення середовища дистанційного навчання в українських ЗВО доцільним $\epsilon$ вивчення досвіду зарубіжних країн із впровадження віддаленого навчання та організації освітнього процесу за допомогою сучасних інформаційно-комунікаційних засобів. Досвід Польщі, яка не лише передова в євроінтеграційних процесах, порівняно з Україною, але й займає порівняно високі показники з реалізації побудови інформаційного суспільства [1], дає підстави для глибшого аналізу та вивчення досягнень польських 3ВО, зокрема приватних.

Аналіз останніх досліджень і публікацій. Проблема дистанційного навчання, насправді, не $\epsilon$ новою, ii вивчають вже впродовж декількох десятиліть науковці 3 усього світу. Проблема використання інформаційнокомунікаційних технологій у навчальному процесі ЗВО активно вивчається українськими та іноземними науковцями та практиками, а саме: Д. Денисова, Н. Балик, Т. Коваль, Ю. Буровицька, М. Кубяк, Дж. Грінберг, Г. Кромптон та інші.

Освітній досвід Польщі став об’єктом досліджень багатьох українських науковців, серед яких А. Василюк, О. Сидоренко, Л. Лук’янова, І. Добрянський, Н. Ничкало, В. Белан та інші.

Водночас сучасні умови диктують необхідність подальшого вивчення зарубіжного досвіду організації дистанційного навчання в 3ВО; за доцільне вважаємо розглянути саме приватні ЗВО Польщі, які мають значні досягнення у цьому питанні.

Мета статті вивчити та проаналізувати сучасний стан організації дистанційного навчання у приватних 3ВО Польщі, виявити особливості цього процесу та окреслити проблемні питання та пріоритетні напрями розвитку дистанційного навчання в ЗВО Польщі.

Виклад основного матеріалу. В сучасній економічній та освітній системах Польщі недержавні 3ВО займають вагоме місце, впроваджуючи нові принципи вищої освіти, сприяючи розширенню доступу до вищої освіти, запроваджуючи нові спеціальностей, орієнтуючись на попит на ринку працю. Впродовж трьох десятків років приватні ЗВО доводять свою значущість, вони отримали визнання серед роботодавців і значне місце на ринку праці, не вимагають державних фінансових вкладень та ресурсів, а лише підтримки та 
неупередженості. На сьогоднішній день вже багато приватних ЗВО Польщі створили сучасні освітні моделі, які функціонують як підприємства освітньої сфери, орієнтуючись на ринок, економічну ситуацію в країні, потреби та запити молоді, одержуючи прибуток з метою подальших інвестицій у розвиток освіти і науки.

3 початку розвитку приватних 3ВО у Польщі однією з їхніх неоціненних переваг та особливостей була зацікавленість у використанні різноманітних інформаційних технологій у навчальному процесі. Ще на початку 2000 років забезпечення приватних ЗВО Польщі комп’ютерним обладнанням відповідало потребам і вимогам інформаційного суспільства. Наприклад, у звіті про розвиток вищої освіти в Польщі зазначено, що недержавні ЗВО використовують 22313 комп'ютерів, а державні - лише 1011 одиниць [2]. Технологічна перевага приватних закладів була помітною не лише для експертів, а й для пересічних громадян, понад $80 \%$ випускників шкіл вважали, що недержавні вищі школи є сучасними освітніми закладам, особливо в технічному аспекті, а $75,3 \%$ - більш гнучкими в організації навчального процесу [3, с. 51].

Аналізуючи науково-практичні матеріали виявлено, що науковці використовують різні терміни для позначення середовища дистанційного навчання, як i їхні трактування та пояснення. У польських виданнях зустрічаються терміни «kształcenia na odległość», «nauczania na odległość», «zdalne nauczanie» або «elektroniczne nauczanie», які переважно стосуються сучасних платформ електронного навчання відомих програмних компаній, що дозволяють впроваджувати дистанційне навчання. освіти та інтерактивного спілкування, а також мають багаторівневі дії, пов'язані між собою [4].

Серед найпопулярніших форм впровадження дистанційної освіти в ЗВО $є$ дистанційне навчання, онлайн навчання та електронне навчання. Відомо, що дистанційне навчання - це спланований досвід навчання та навчання, який використовує широкий спектр технологій для дистанційного охоплення учнів і призначений для заохочення взаємодії учнів та сертифікації навчання [5, с. 36]. Польський учений М. Кубяк визначає дистанційне навчання як «метод проведення дидактичного процесу в умовах, коли вчителі та студенти віддалені один від одного і не перебувають на одному місці, використовуючи сучасні методи передачі інформації - крім традиційних методів спілкування, сучасні телекомунікаційні технології, пересилання голосу, відео, комп'ютерних даних та друкованих матеріалів. Сучасні технології також забезпечують прямий контакт у реальному часі між викладачем та учнем через аудіо- або відеоконференцію, незалежно від відстані» [6, с.11]. Загалом, прийнято вважати, що термін «онлайн-навчання» застосовується, коли вчителі або студенти використовують освітні засоби, доступні в Інтернеті. 3 іншого боку, існує також мобільне навчання як метод навчання в різних контекстах, через соціальні та контентні взаємодії з використанням персональних електронних пристроїв [7]. Безсумнівно, мобільне навчання можна використовувати і в 
аудиторному навчанні як додаткові засоби для удосконалення і осучаснення навчального процесу.

Поряд $з$ тим, що вже впродовж десятиліть науковці займаються вивченням питань виявлення переваг і недоліків, перспектив і проблем онлайн навчання, використанням різних інформаційно-комунікаційних технологій у навчальному процесі вони залишаються й надалі актуальними, а в сучасних умовах необхідності дистанційного навчання їхня актуальність лише зросла.

Одною із переваг дистанційного навчання для 3ВО, а особливо приватних, $\epsilon$ економічна ефективність таких форм навчання, оскільки використання інформаційно-комунікаційних технологій мінімізує певні фінансові витрат освітніх закладів, тобто при збільшенні кількості студентів, накладні витрати залишаються незмінними (зменшується кількість аудиторного фонду, витрати на комунальні послуги, тощо). Це спонукало деяких авторів стверджувати, що «країни, що розвиваються, звертаються до дистанційних освітніх програм, щоб усунути невідповідність кількості навчальних приміщень до дедалі зростаючого рівня студентів, яких зараховують на навчання» [8, с. 29]. Очевидним залишається факт, що заочне i дистанційне навчання у недержавних 3ВО Польщі стали важливими формами надання освітніх послуг молоді та дорослим, які не мають змоги навчатися стаціонарно. Адже, студенти заочної форми навчання відвідуючи заняття лише 4 дні на місяць i, проходячи дистанційні програми, отримують таку ж кваліфікацію, навички та дипломи, що й студенти очної форми навчання.

Загалом, процес організації дистанційного навчання у 3ВО Польщі регулюється відповідними законами і нормативно-правовими документами, які визначають цей процес $\mathrm{i}$ визнають необхідність використання i розвитку інформаційно-комунікаційних технологій в освітньому процесі, серед яких Закон «Про вищу освіту і науку» (2018р.), Резолюція «Про побудову інформаційного суспільства в Польщі» (2000р.), Закон «Про конкретні рішення, пов’язані із запобіганням, профілактикою та боротьбою із COVID-19, інших інфекційних захворювань і кризових ситуацій, спричинених ними» (2020р.), документ «Цілі та напрями розвитку інформаційного суспільства в Польщі».

Встановлено, що дистанційне навчання сприймається більшістю польських недержавних ЗВО як доповнення до денного курсу, невід'ємна частина онлайн-курсів, а також як форма заочної форми навчання, оскільки заняття можна проводити дистанційно, використовуючи онлайн-технології, Інтернет-ресурси та відео конференції без необхідності відвідувати заняття. 3 кожним роком зростає кількість приватних ЗВО, які впроваджують як елементи електронного навчання на заочній формі навчання, так і розвивають онлайн-курси як форми дистанційного навчання. Зазначимо, що курси дистанційного навчання класифікуються за критерієм застосування методів i прийомів електронного навчання [4]:

1) онлайн-курси повністю доступні в Інтернеті, всі лекції, майстер-класи, спілкування також проводяться через Інтернет-ресурси; 
Журнал«Герспективита іновації науки»

(Серія«Гедагогіка», Серія«ГТихологія», Серія«Медицинв»

№5(5) 2021

2) дистанційний курс є лише доповненням до денної форми навчання, зменшується кількість очних занять, збільшується доступ до матеріалів курсу (доступні також електронні версії матеріалів);

3) традиційна освіта лише збагачується новітніми технологіями: мережевими ресурсами, електронною поштою, мобільними додатками тощо.

Встановлено, що приватні ЗВО Польщі впродовж свого існування демонструють зацікавленість та готовність проводити заняття в різних формах і режимах з використанням синхронної та асинхронної комунікації; дбають про якість викладання та безперервний процес надання освітніх послуг як в очній, так і дистанційній формах; зосереджені на інтереси та потреби студентів, оскільки фінансова стабільність цих закладів значною мірою залежить від їхньої оплати. Для підтвердження цього, розглянемо досвід реалізації онлайн навчання в окремих приватних ЗВО Польщі.

Одним із відомих польських недержавних $3 \mathrm{BO}$ у впровадженні електронного навчання $\epsilon$ Гуманітарно-економічний університет у Лодзі, де ще в 2002 році було запропоновано перше онлайн навчання 3 менеджменту та маркетингу та інформатики. Згодом на базі цього університету був створений Польський віртуальний університет, де сьогодні студенти мають можливість обрати спеціальність першого бакалаврського рівня 3-поміж 16 різних, навчання в магістратурі чи аспірантурі, а також повністю англомовні бакалаврські програми з графіки чи менеджменту, інженерську з комп'ютерних наук та магістерську з політичних наук.

Варто звернути увагу на навчальний процес у Польському віртуальному університеті, де впродовж семестру відсутність очних занять компенсується використанням платформи дистанційного навчання, однак є й очні заняття 2-3 рази на семестр. Кожен предмет складається з модулів, які вивчаються та виконуються студентами індивідуально у власному темпі та у зручний час, однак $€$ чіткий графік кінцевих термінів виконання модульних завдань. Спілкування зі студентами організовується в асинхронному режимі (студенти не повинні бути присутніми одночасно) - дискусійний форум, внутрішня електронна пошта, он-лайн простори для командної роботи, надсилання папок 3 матеріалами; або синхронно (в узгоджений зі студентами час) - вебінари, чати, відеоконференції. Екзаменаційна сесія $\epsilon$ обов'язковою в приміщенні університету перед екзаменаційною комісією. Тільки через поточну ситуацію 3 пандемією всі іспити також проходять онлайн. Щоб отримати ступінь студенти цього університету також пишуть та захищають дипломні роботи.

Цікавим прикладом реалізації дистанційного навчання є Університет інформаційних технологій та менеджменту в Жешуві (WSIiZ - Wyższa Szkoła Informatyki i Zarządzania), який був заснований у 1996 році, а сьогодні це найбільший та найбільш рейтинговий приватний 3ВО у південно-східному регіоні Польщі. Він один із перших запровадив інтегровану систему управління університетом «Віртуальний вищий навчальний заклад», а також новітню форму заочного навчання - Інтерактивну систему навчання. Впродовж 
багатьох років цей університет проводить онлайн заняття за допомогою інструменту Collaborate на платформі Blackboard, яка $\epsilon$ американською навчальною платформою та однією 3 найпоширеніших у світі. Використовуючи ноутбуки чи смартфони, студенти мають доступ до різних навчальних матеріалів, беруть участь у різноманітних онлайн заняттях, які проводять викладачі університету, виконують проекти та вільно співпрацюють 3 іншими студентами, використовуючи передові інструменти для спільної роботи для текстових, голосових та відеокомунікацій.

Важливо зазначити, що в сучасних умовах, коли всі ЗВО були змушені організувати навчання в режимі онлайн, студенти та викладачі переоцінили вагомість дистанційного навчання. У цьому контексті дистанційне навчання вже, здебільшого, розглядається як складний процес, що поєднує онлайн технології, платформи та ресурси з інструментами відеоконференцій з метою активного залучення студентів до навчального процесу, мінімізуючи відсутність живої комунікації, співпраці та взаємодії. Адже дистанційне навчання не може бути перешкодою для отримання якісних освітніх послуг; навпаки, це дає студентам, викладачам та ЗВО широкі можливості для навчання, оволодіння новими навичками та отриманням знань, незважаючи на ситуацію з пандемією; це сприяє рівноправному доступу до вищої освіти, залучаючи більше студентів, незважаючи на їхній вік, відстань та часовий пояс. Професор Ян Шмідт, ректор Варшавського технологічного університету, зазначає, що в умовах дистанційного навчання «студенти раптом почали розуміти, що вони повинні вчитися, а не їх мають навчати, адже вища освіта це, перш за все, самоосвіта» [9].

Аналізуючи діяльність недержавних 3ВО Польщі, встановлено, що багато 3 них вже розробили ефективну систему віддаленого навчання, щоб задовольнити зацікавленість поляків у отриманні вищої освіти шляхом неформального навчання, у забезпеченні якого значну роль відіграє саме дистанційне навчання. Виявлено, що сьогодні 47\% дорослих у Польщі беруть участь у програмах неформальної освіти та навчання, які навчаються в дистанційному режимі, порівняно з 20\% у середньому по країнах Європи [10], що, звичайно, потребує зі сторони ЗВО обдуманого та комплексного підходу. Оскільки, комп'ютерна техніка не здатна самостійно підвищити якість запропонованого навчання, саме тому з'являються нові виклики та додаткові завдання перед ЗВО, серед яких:

- створення та апробація власних методів віддаленого навчання;

- розробка інноваційних навчальних програм;

- створення дидактичних мультимедійних матеріалів;

- оформлення тематичних освітніх порталів;

- придбання нових цифрових пристроїв, апаратного та програмного забезпечення;

- підготовка та перепідготовка професорсько-викладацького складу для роботи з методами та засобами електронного навчання. 
Журнал«Герспективитаінновації наукиљ

(Серія«Гедагогіка»), Серія«ГТихологія», Серія «Медицина»

№5(5) 2021

Поряд із виникненням додаткових завдань через реалізацію дистанційного навчання, з'являються ще й певні проблеми в недержавних ЗВО Польщі, які часто пов'язані між собою і впливають на якість дистанційного навчання, серед них ми виокремлюємо:

- забезпечення якісних матеріалів для онлайн навчання;

- приховані витрати на апаратне та програмне забезпечення;

- проблеми 3 технікою, тому що збій програмного або апаратного забезпечення може вплинути на ефективність занять;

- індивідуальне ставлення професорсько-викладацького складу та студентів до такої форми навчання, адже від їх умінь, знань та бажання багато в чому залежить результат навчання.

Сьогодні, недержавні ЗВО Польщі не лише займаються вирішенням нагальних питань та проблем із впровадженням дистанційного навчання на всіх рівнях навчання, а й подоланням нового фінансового виклику. Адже через недостатні фінансові ресурси багатьох студентів, які здебільшого фінансують приватну вищу освіту (75\% загального операційного доходу надходить від плати за навчання і лише 10,1\% від субсидій на підтримку викладацького та наукового потенціалу) і відповідно їхній відтік, деякі недержавні ЗВО, особливо невеликі, знаходяться під загрозою закриття.

Оскільки Міністерство освіти і науки Польщі вважає, що вища освіта в Польщі є єдиною, «хоча вона поділяється на державні та недержавні заклади, але всі навчають і готують молодь для загального блага» [9], до цього ж багато приватних вищих шкіл вже мають значні досягнення, розвинені структури та сучасні моделі навчання і надають якісні освітні послуги, тому було прийнято рішення щодо підтримки недержавних ЗВО. 3 метою забезпечення відповідних умов дистанційного навчання для закладів приватного сектору вищої освіти виділяється 10 мільйонів злотих 3 державного бюджету [11]. Зазначимо, що недержавні ЗВО можуть використовувати виділені кошти лише на те, щоб покращити дистанційне навчання, а саме на:

- придбання програмного забезпечення (віртуалізація спеціалізованих лабораторій, ліцензії на програми дистанційної освіти тощо);

- придбання обладнання (у тому числі ноутбуків, планшетів, серверів, модемів, пристроїв, необхідних для обладнання навчальних кабінетів системами відео-конференц зв'язку тощо);

- придбання доступу до віртуальних бібліотек (надання студентам доступу до електронних видань або електронних підручників, а також доступ до електронних ресурсів, що допоможе студентам у написанні випускних робіт та підготовці до занять);

- винагорода для осіб, відповідальних за підтримку науково-педагогічних працівників та студентів у сфері онлайн-занять (тобто програмістів, методистів, людей, які готують мультимедійні матеріали);

- навчання науково-педагогічного складу.

Очікується, що близько 100 приватних ЗВО отримають таку державну 
підтримку, це ті, які у 2018-2020 роках не отримали негативної оцінки якості освіти за жодним із напрямів навчання, а також ті, в яких навчалося не менше 100 студентів денної форми навчання (за даними, представленими до 31 грудня 2019 р. Інтегрованою інформаційною системою вищої освіти і науки POL-on).

Висновки. Отож, впродовж останніх двох років сучасне суспільство осягнуло вагомість дистанційного навчання, адже воно надало можливість не перервати навчальний процес навіть за найбільш критичних соціальноекономічних умов. У час локдауну перехід до нового навчального процесу, який повністю залежить від комп'ютерів, інтернету, передових технологій, додатків та платформ, не був для приватних ЗВО Польщі надто стресовим чи незрозумілим. Аналіз проблем та досягнень приватних 3ВО Польщі в реалізації дистанційного навчання доводить, що успішність процесу організації віддаленого навчання залежить не лише від цифрової компетентності науковопедагогічних працівників 3ВО, їхнього ентузіазму і обізнаності в новітніх інформаційно-комунікаційних технологіях, але й виважених i своєчасних організаційних заходів зі сторони навчальних закладів, фінансової підтримки зі сторони держави у вигляді субсидій та додаткових виплат, належного нормативно-правового регулювання і загально сприйняття суспільством нових форм навчального процесу та надання онлайн освітніх послуг. Застосування інноваційного польського досвіду 3 питань дистанційного навчання в освітньому процесі українських ЗВО є доцільним, оскільки процес подальшого поширення дистанційного навчання $€$ незворотнім, а збільшення кількості повноцінних онлайн навчальних курсів з різних спеціальностей та на різних освітніх рівнях, і створення віртуальних факультетів та інститутів це - лише питання часу.

Проведене дослідження не претендує на цілісне висвітлення означеної проблеми, а відкриває перспективи подальших наукових розвідок 3 питань організації дистанційного навчання в різних країнах, вивчення досвіду створення онлайн курсів, віртуальних освітніх середовищ тощо.

\section{Jimepamypa:}

1. ICT Development Index 2017. World ranking [online]. [Електронний ресурс]. - Режим доступу: http://www.itu.int/net4/ITU-D/idi/2017/\#idi2017rank-tab

2. Szablowski J. 700 tys. absolwentow / J. Szablowski // Forum Akademickie. - 2007. - №1.

3. Nowakowska J. Grant wewnetrzny. Wizerunek uczelni niepanstwowych wsrod maturzystow w Polsce / J. Nowakowska, A. Ordon, A. Rozmus // Zaklad Badan nad Szkolnictwem Wyzszym. Rzeszow. - 2007. - 167 s.

4. O kształceniu na odległość (KNO). [Електронний ресурс]. - Режим доступу: https://www.wshleszno.pl/ksztalcenie-zdalne---kno-moodle/o-ksztalceniu-na-odleglosc-kno

5. Greenberg G. Distance education technologies: Best practices for K-12 settings / G. Greenberg // IEEE Technology and Society Magazine, (Winter). - 1998. - P. 36-40.

6. Kubiak M. Wirtualna edukacja / M. Kubiak // Warszawa, Wydawnictwo "MIKOM", 2000.

7. Crompton H. A historical overview of mobile learning: Toward learner-centered education / H. Crompton // Handbook of mobile learning. Publisher: Routledge. Editors: Z. L. Berge \& L. Y. Muilenburg. - 2013. - P. 3-14. 
8. Bollag B. Developing countries turn to distance education / B. Bollag, M.A. Overland // Chronicle of Higher Education. - 2001. - 47 (40). - P. 29-31.

9. Jastrzębska L. Jesteśmy w nadzwyczajnym czasie [Електронний pecypc] / L. Jastrzębska // Perspektywy. Newsletter Akademicki. - 2020. - Режим доступу: https://perspektywy.pl/portal/ index.php?option=com_content\&view=article\&id=4822:jestesmy-w-nadzwyczajnym-czasie\&catid= 24\&Itemid=119

10. Education at a Glance 2019: OECD Indicators [Електронний ресурс]. Paris: OECD Publishing, 2019. - Режим доступу: https://doi.org/10.1787/f8d7880d-en

11. $10 \mathrm{mln}$ zł wsparcia dla uczelni niepublicznych na nauczanie zdalne. Ministerstwo Edukacji i Nauki, 2021. - [Електронний pecypc]. - Режим доступу: https://www.gov.pl/web/ edukacja-i-nauka/10-mln-zl-wsparcia-dla-uczelni-niepublicznych-na-nauczanie-zdalne

\section{References:}

1. ICT Development Index 2017. (2017). World ranking [online]. Retrieved from: http://www.itu.int/net4/ITU-D/idi/2017/\#idi2017rank-tab

2. Szablowski, J. (2007). 700 tys. absolwentow [700 thousand graduates]. Forum Akademickie - Academic Forum, №1 [in Polish].

3. Nowakowska, J., Ordon, A., Rozmus A. (2007). Grant wewnetrzny. Wizerunek uczelni niepanstwowych wsrod maturzystow w Polsce [Internal grant. The image of non-state universities among high school graduates in Poland]. Zaklad Badan nad Szkolnictwem Wyzszym. Rzeszow, 167. [in Polish].

4. O kształceniu na odległość (KNO) [About distance learning]. Retrieved from: https://www.wshleszno.pl/ksztalcenie-zdalne---kno-moodle/o-ksztalceniu-na-odleglosc-kno [in Polish].

5. Greenberg, G. (1998). Distance education technologies: Best practices for K-12 settings. IEEE Technology and Society Magazine, (Winter), 36-40.

6. Kubiak, M. (2000). Wirtualna edukacja [Virtual education]. Warszawa, Wydawnictwo "MIKOM" [in Polish].

7. Crompton, H. (2013). A historical overview of mobile learning: Toward learner-centered education. Handbook of mobile learning. Z. L. Berge \& L. Y. Muilenburg (Eds.). Publisher: Routledge, 3-14.

8. Bollag, B., \& Overland, M.A. (2001). Developing countries turn to distance education. Chronicle of Higher Education, 47 (40), 29-31.

9. Jastrzębska, L. (2020). Jesteśmy w nadzwyczajnym czasie [We are in an extraordinary time]. Perspektywy. Newsletter Akademicki - Perspectives. Academic Newsletter. Retrieved from: https://perspektywy.pl/portal/index.php?option=com_content\&view=article\&id=4822:jestesmy-wnadzwyczajnym-czasie \&catid=24\&Itemid=119 [in Polish].

10. Education at a Glance 2019: OECD Indicators. (2019). OECD Publishing, Paris. Retrieved from: https://doi.org/10.1787/f8d7880d-en

11. 10 mln zt wsparcia dla uczelni niepublicznych na nauczanie zdalne [10 million PLN of support for private universities for distance learning]. (2021). Ministerstwo Edukacji i Nauki. Retrieved from: https://www.gov.pl/web/edukacja-i-nauka/10-mln-zl-wsparcia-dla-uczelni-niepublicznych- na-nauczaniezdalne [in Polish]. 